O Processo de Elaboração da Leitura e da Escrita numa Abordagem Sódo-ínteracionista Desafios de uma Avaliação

Pesquisadora: Maria Alice Setúbal Souza e Silva

Instituição: Centro de Pesquisas para Educação e Cultura (CENPEC)

Fonte Financiadora: INEP

A questão do fracasso escolar permanece ainda hoje um dos grandes desafios da educação no Brasil, como tem sido analisada em diversos estudos. No bojo da discussão acerca do fracasso escolar, a problemática relativa às séries iniciais persiste como uma das preocupações primordiais de pesquisadores e educadores, diante da permanência de altos índices de repetência e evasão escolar, tanto em relação ao Brasil como ao Estado de São Paulo.

Neste sentido, assistimos nos últimos anos a uma crescente produção de trabalhos que têm como objeto de pesquisa questões relativas à alfabetização.

Acreditamos, no entanto, que se fazem necessários estudos que ampliem o número de participantes envolvidos nas diferentes propostas alternativas desenvolvidas no contexto escolar, de modo que possamos obter dados mais amplos e significativos, que, sustentados numa prática de sala de aula, nos dêem subsídios para um aprofundamento do processo de elaboração da língua escrita $A$ inexistência, na literatura nacional, de dados mais amplos e também mais apurados acerca do processo de construção da leitura e escrita numa abordagem sócio-interacionista, nos coloca ainda muitas dúvidas com relação ao desenvolvimento desse processo e dos fatores que nele intervém, no sentido de permitir propostas de caminhos possíveis que possibilitem uma ampliação desse tipo de proposta, na realidade educacional brasileira. É dentro dessa perspectiva que colocamos para nós o desafio de realizar uma avaliação, envolvendo aspectos qualitativos e quantitativos, de uma proposta já em andamento em escolas da rede pública da Grande São Paulo.

\section{O Programa de Leitura e Escrita}

A elaboração do Programa de Leitura e Escrita (objeto de nossa avaliação) teve como ponto de partida a reflexão sobre questões relativas à construção da leitura e da escrita e às condições reais da escola pública de São Paulo. Acreditamos que a consecução desse programa adquire significado se levarmos em conta não apenas os altos índices de repetência e evasão escolar ainda hoje existentes, como também a criação de um subsídio para que o professor possa trabaIhar numa nova proposta de alfabetização, tendo como apoio um material didático satisfatório. Diante de todas as dificuldades enfrentadas pela escola pública, é muito difícil para o professor, que não tem, na maioria das 
vezes, uma orientação e um preparo adequado, implantar sozinho, sem nenhum material, uma nova maneira de trabalhar a leitura e a escrita Obviamente, é importante ter-se consciência do limite do livro didático, que por si só não oferece condições de mudança, sendo apenas um elemento que pode (ou não) garantir um melhor ensino.

O programa pretende dar ao professor os instrumentos para uma nova abordagem da leitura e da escrita $\mathrm{O}$ objetivo é que o professor, ao se apropriar dos pressupostos dessa abordagem, possa utilizá-los como um apoio, criando novas atividades, de acordo com a dinâmica e as necessidades específicas da classe.

\section{A pesquisa}

Os dados para realização da pesquisa foram coletados em 19 classes de $1^{a}$ série, de sete escolas da rede pública da Grande São Paulo, localizadas nas regiões de Carapiculba, Barueri e cidade de São Paulo, totalizando um número de 616 crianças. Para a análise dos dados coletados, optou-se por construir uma amostra reunindo apenas as crianças que tivessem participado dos cinco momentos da coleta de dados.

O número de casos analisados alcançou um total de 364 crianças, representando $59 \%$ dos alunos participantes do projeto.

Para a consecução da avaliação foram elaborados cinco instrumentos de coleta de dados, todos aplicados de forma coletiva na classe. O primeiro deles constituiu-se de um conjunto de nove palavras e uma frase, de modo que se pudesse analisar como se configuram os conhecimentos das crianças acerca da língua escrita, no início do ano.

Os quatro outros instrumentos foram elaborados na forma de provas, procurando nelas inserir os pressupostos gerais e os objetivos específicos do programa, durante as diferentes etapas do ano letivo.

Cada um dos quatro instrumentos era composto por 12 atividades, a serem avaliadas, e foi construído levando-se em conta os objetivos esperados naquela etapa, contendo como tópicos principais: 1) construção de palavras; 2) conhecimento das convenções da escrita; 3) conhecimento de noções lingüísticas; 4) leitura; 5) produção de texto.

A aplicação das provas foi feita pelas próprias professoras da classe. Para cada prova foram feitas reuniões onde se discutiam os objetivos de cada questão apresentada, se resolviam as dúvidas, e se explicitava o modo como os professores deveriam proceder com seus alunos.

Para a correção das provas foram treinados dois corretores, que tomaram conhecimento do Programa de Leitura e Escrita como um todo, assim como de seus pressupostos e objetivos. Para cada prova, foram discutidos os objetivos e as categorias de correção, realizando-se uma prétestagem entre os corretores, de modo que se obtivesse o máximo de consistência possível.

A elaboração das categorias de correção foi realizada tendo em vista os conceitos implícitos em cada questão e também as possibilidades de 
respostas obtidas após uma primeira verificação geral das provas.

\section{Resultados}

$\mathrm{Na}$ primeira etapa da análise dos resultados obtidos procuramos focalizar a atenção no desempenho das crianças nos diferentes momentos do ano letivo, de modo a apreender a evolução da leitura e da escrita durante esse período. Essa abordagem inicial revelou a tendência geral encontrada na evolução da escrita, e não as suas relações com cada grupo-classe e as especificidades constituintes desse processo. Embora a análise ainda esteja em andamento, podemos destacar alguns aspectos: 1 ) A constatação de um grande salto qualitativo no desempenho das crianças, da primeira para a segunda avaliação. Podemos atribuir esse resultado ao efeito do processo escolar como um todo: interações com o professor, com os colegas e com o conteúdo das atividades de língua escrita; 2) Os resultados de cada uma das avaliações refletem a diversidade do processo de aprendizagem das crianças, ou seja, o professor depara-se durante todo o ano com uma heterogeneidade intragrupal; 3) A importância do papel desempenhado pela escola - apoio e implementação das condições necessárias ao desenvolvimento de uma proposta pedagógica - nos resultados alcançados pelas crianças; 4) A interferência do fator greve no resultado da evolução da escrita 